Plant Tissue Cult. \& Biotech. 24(1): 47-55, 2014 (June)

$\overline{\text { PTC\&B }}$

\title{
Heavy Metals and Nanoparticles: Impact on Protocorm- like Body Formation in Hybrid Cymbidium
}

\author{
Jaime A. Teixeira da Silva*
}

Faculty of Agriculture and Graduate School of Agriculture, Kagawa University, Miki-cho, Kagawa, 761-0795, Japan

Key words: Heavy metals, Nanotechnology, Teixeira Cymbidium (TC) medium

\begin{abstract}
Heavy metals (HMs) typically inhibit plant growth and development. Only HM accumulators are able to tolerate the presence of these toxic compounds. No studies exist on the response of any orchid cultures to $\mathrm{HMs}$ or to nano-particles. In this study, all $\mathrm{HMs}$ tested ( $\mathrm{Al}, \mathrm{As}, \mathrm{Cd}, \mathrm{Cr}, \mathrm{Cu}, \mathrm{Hg}, \mathrm{Ni}, \mathrm{Zn}$ ) fully reduced neoPLB growth at or greater than $100 \mu \mathrm{M}$. Some neo-PLB growth was observed at 10 and $50 \mu \mathrm{M}$, but the levels were significantly lower than the control treatments. Thin cell layers necrosed even at $50 \mu \mathrm{M}$, while levels of neo-PLB formation were extremely low at $10 \mu \mathrm{M}$. When 100 and $400 \mathrm{mg} / \mathrm{l}$ of nano- $\mathrm{SiO}_{2}$ and nano- $\mathrm{TiO}_{2}$ were added to 10 and $50 \mu \mathrm{M}$ of all HMs, in a bid to try and mitigate the negative effects of the HMs and improve neo-PLB formation, there was no improvement to neo-PLB formation. Hybrid Cymbidium is thus an extremely HM-sensitive species.
\end{abstract}

\section{Introduction}

The concentrations of heavy metals (HMs) in soil range from $<1 \mathrm{mg} / \mathrm{kg}$ to as much as $100,000 \mathrm{mg} / \mathrm{kg}$, caused by natural geological deposits or formation, or as a result of anthropogenic activity such as mining or the application of pesticides for pest control (Pilon-Smits 2005). There is a wealth of literature on the negative impacts of HMs on plant growth and an equally wide range of studies reporting on the ability of plants to take up toxic levels of HMs, i.e., phytoremediation and phytoaccumulation such as by Manousaki and Kalogerakis (2011). The in vitro environment has been an effective biotechnological tool for selecting for HMtolerant lines or against HM-sensitive lines (reviewed by Doran 2009 and Rai et al. 2011). For example, Nehnevajova et al. (2007) used in vitro breeding and

*Present address: P. O. Box 7, Miki-cho post office, Ikenobe 3011-2, Kagawa-ken, 761-0799, Japan.<jaimetex@yahoo.com> 
somaclonal variation to improve the potential of Indian mustard (Brassica juncea L.) to extract and accumulate toxic HMs, culturing callus on medium supplemented with 10-200 $\mu \mathrm{M} \mathrm{Cd}, \mathrm{Zn}$ or $\mathrm{Pb}$, generating new somaclones with improved tolerance to these three HMs. However, some $\mathrm{HMs}$ such as $\mathrm{Co}, \mathrm{Cu}, \mathrm{Fe}$, $\mathrm{Mn}, \mathrm{Mo}, \mathrm{Ni}$ or $\mathrm{Zn}$ are essential micronutrients for the physiological and metabolic functioning of plants while $\mathrm{Pb}, \mathrm{Cd}, \mathrm{Cr}, \mathrm{Ag}, \mathrm{Sb}$ and $\mathrm{Hg}$ have no known biological function as nutrients in plants (Marschner 1995); so both a deficit and excess of such HMs can negatively impact plant growth and development. There are a wide range of plant species that are resistant to arsenic (As), a metalloid (Meharg and Hartley-Whitaker 2002). The lanthanoids, or rare earth metals, have shown ability to stimulate new or neo-protocorm-like bodies (PLBs) and axillary roots in hybrid Cymbidium (Teixeira da Silva unpublished). There are no studies on the use of orchid in vitro cultures to examine the effects of HMs on growth and development nor are there any studies on the use of nanotechnology in orchid research (Hossain et al. 2013, Teixeira da Silva 2013a). Based on this gap in the literature, this study was conducted to assess the impact of HMs on neo-PLB induction and organogenesis of hybrid Cymbidium in vitro. Many media can support the induction and development of Cymbidium PLBs in vitro (Teixeira da Silva et al. 2005), but Teixeira Cymbidium (TC) No. 1 medium (Teixeira da Silva 2012) was used in this study. PLBs are considered to be somatic embryos in orchids (Teixeira da Silva et al. 2006a) and were thus fulfil the optimal unit of propagation for this study.

Nanomaterials, used within nanotechnology, are seen increased use in agriculture (Mousavi and Rezaei 2011). Due to their size, they can change physico-chemical properties and have a greater surface area more than their bulk materials and because of the larger surface area, their solubility and surface reactivity is also higher (Castiglione and Cermonini 2009). $\mathrm{Nano}^{-\mathrm{TiO}_{2}}$ (nanotitanium dioxide) increased nutrient uptake in tomato (Haghighi et al. 2012), while $\mathrm{Si}$, applied as nano- $\mathrm{SiO}_{2}$ (nano-silicon dioxide) ameliorated the detrimental effects of salt stress (Haghighi et al. 2013). The benefits of Si in alleviating abiotic stress are well documented (Liang et al. 2007). There are other examples where nano- $\mathrm{TiO}_{2}$ and nano- $\mathrm{SiO}_{2}$ have shown a positive effect on plant growth, but most of these have been greenhouse studies. Furthermore, in all those studies, there has always been a threshold level between a positive effect and toxicity (e.g., Lin and Xing 2007), which is usually dependent on the plant material, e.g. cultivar, species, etc. 


\section{Materials and Methods}

All protocols (experimental design, chemicals, reagents, explant preparation and treatment analysis) applicable to PLB culture establishment and proliferation (i.e., neo-PLB formation) strictly followed Teixeira da Silva et al. (2005, 2006a, 2006b), Teixeira da Silva (2013b), and Teixeira da Silva and Dobránszki 2013). All chemicals and reagents were of the highest analytical grade available and were purchased from either Sigma-Aldrich (St. Louis, MO, USA), Wako Chemical Co. (Osaka, Japan) or Nacalai Tesque (Kyoto, Japan), the cheapest choice at the highest tissue culture grade, unless specified otherwise.

PLBs of hybrid Cymbidium Twilight Moon 'Day Light' (Bio-U, Tokushima, Japan), originally developed from shoot-tip cultures on VW (Vacin and Went 1949) agar medium without plant growth regulators, were induced and subcultured (PLB induction and proliferation medium) every two months on Teixeira Cymbidium (TC) No. 1 medium (Teixeira da Silva 2012), which contains $0.1 \mathrm{mg} / \mathrm{l} \mathrm{NAA}$ and $0.1 \mathrm{mg} / \mathrm{l} \mathrm{Kn}, 2 \mathrm{~g} / 1$ tryptone and $20 \mathrm{~g} / 1$ sucrose, and solidified with $8 \mathrm{~g} / \mathrm{l}$ Bacto agar (Difco Labs., USA). All media were adjusted to $\mathrm{pH} 5.3$ prior to autoclaving at $100 \mathrm{KPa}$ for $17 \mathrm{~min}$. Cultures were kept on $40 \mathrm{ml}$ medium in 100 $\mathrm{ml}$ Erlenmeyer flasks, double-capped with aluminum foil, at $25^{\circ} \mathrm{C}$, under a $16 \mathrm{hrs}$ photoperiod with a light intensity of $45 \mu \mathrm{mol} / \mathrm{m}^{2} / \mathrm{s}$ provided by $40 \mathrm{~W}$ plant growth fluorescent lamps (Homo Lux, Matsushita Electric Industrial Co., Japan). Longitudinally dissected as two pieces of PLB (3 - $4 \mathrm{~mm}$ in diameter) segments (Teixeira da Silva 2013b), hereafter half-PLBs, 10/flask, were used as explants for neo-PLB induction and proliferation.

At 60 days after treatment, the growth and developmental response was represented by three parameters: (1) Percentage of half-PLBs forming neo-PLBs; (2) Number of neo-PLBs formed per half- PLB; (3) Fresh weight (mg) of half-PLB + neo-PLBs. Four concentrations $(0,10,50,100,500 \mu \mathrm{M})$ of $8 \mathrm{HMs}: \mathrm{Al}$ as $\mathrm{Al}_{2}\left(\mathrm{SO}_{4}\right)_{3}$, As as $\mathrm{Na}_{2} \mathrm{HAsO}_{4}, \mathrm{Cd}$ as $\mathrm{Cd}\left(\mathrm{NO}_{3}\right)_{2} \cdot 4 \mathrm{H}_{2} \mathrm{O}, \mathrm{Cr}$ as $\mathrm{K}_{2} \mathrm{Cr}_{2} \mathrm{O}_{7}, \mathrm{Cu}$ as $\mathrm{CuSO}_{4} \cdot 5 \mathrm{H}_{2} \mathrm{O}, \mathrm{Hg}$ as $\mathrm{HgCl}_{2}, \mathrm{Ni}$ as $\mathrm{Ni}\left(\mathrm{NO}_{3}\right)_{2}$, and $\mathrm{Zn}$ as $\mathrm{Zn}\left(\mathrm{NO}_{3}\right)_{2} \cdot 6 \mathrm{H}_{2} \mathrm{O}$. The valency of each $\mathrm{HM}$ has not been specified.

For example, hexavalent $\mathrm{Cr}, \mathrm{Cr}(\mathrm{VI})$ or $\mathrm{Cr}+6$ is, in this study, simply represented by the elemental code, $\mathrm{Cr}$. Nano- $\mathrm{SiO}_{2}$ and nano- $\mathrm{TiO}_{2}$ were purchased from Sigma-Aldrich with particle sizes ranging from 10 to $20 \mathrm{~nm}$. Nanoparticles were dispersed in distilled water at one concentration $(1 \mathrm{~g} / \mathrm{l})$ by ultrasonication at $60 \mathrm{~Hz}$ for $30 \mathrm{~min}$ and then sterilized at $120^{\circ} \mathrm{C}$ and $100 \mathrm{KPa}$ for $20 \mathrm{~min}$. This served as the stock solution from which desired dilutions were prepared. For two concentrations of HMs $(10,50 \mu \mathrm{M})$, i.e., concentrations where some growth and development of neo-PLBs was registered, nano- $\mathrm{SiO}_{2}$ and nano$\mathrm{TiO}_{2}$ were added to basal TC medium at two concentrations (100 and $400 \mathrm{mg} / \mathrm{l}$ ). 
The latter concentrations were based on anecdotal evidence of the mitigating effect of nano- $\mathrm{SiO}_{2}$ and the growth-stimulatory effect of nano- $\mathrm{TiO}_{2}$ on crops, horticultural plants, medicinal plants and weeds (Teixeira da Silva, unpublished data).

Experiments were organized according to a randomized complete block design with three blocks of 10 replicates per treatment (i.e., HM concentration). All experiments were repeated in triplicate $(n=30$, total sample size per treatment). The resulting organogenic outcome (neo-PLB or root response) was scored visually after 60 days, 60 days being the optimal time for sampling (Teixeira da Silva and Dobránszki 2013). Data were subjected to ANOVA with mean separation by DMRT using SAS® version 6.12 (SAS Institute, Cary, NC, USA). Significant differences between means were assumed at $\mathrm{p} \leq 0.05$.

\section{Results and Discussion}

The most notable finding of this paper is that all HMs fully reduced neo-PLB growth at or greater than $100 \mu \mathrm{M}$ (Figs 1, 2). Some neo-PLB growth was observed at 10 and $50 \mu \mathrm{M}$, but the levels were significantly lower than the control treatments. Thin cell layers (TCLs), which are more sensitive explants for in vitro studies (Teixeira da Silva 2013b), necrosed even at $50 \mu \mathrm{M}$, while levels of neoPLB formation were extremely low at $10 \mu \mathrm{M}$ (data not shown). Based on unpublished, anecdotal evidence of the mitigating effect of nano- $\mathrm{SiO}_{2}$ and the growth-stimulatory effect of nano- $\mathrm{TiO}_{2}$ on crops, horticultural plants, medicinal plants and weeds (Teixeira da Silva, unpublished data), 100 and $400 \mathrm{mg} / \mathrm{l}$ of nano- $\mathrm{SiO}_{2}$ and nano- $\mathrm{TiO}_{2}$ were added to 10 and $50 \mu \mathrm{M}$ of all $\mathrm{HMs}$, in a bid to try and mitigate the negative effects of the HMs and improve neo-PLB formation. Regrettably, neo-PLB formation did not improve in the presence of either nanoparticle, at either concentration (data not shown). These results suggest that hybrid Cymbidium is an extremely HM-sensitive species, which could also lend it as a useful model plant for in vitro toxicity tests.

The literature is full of studies related to the (mostly) negative impacts of HMs on plant growth, in vitro or in hydroponic or greenhouse studies, so only a handful of representative studies will be discussed below.

Seed germination, as well as shoot and root growth of alfalfa were negatively impacted by $20 \mathrm{mg} / \mathrm{l}$ of $\mathrm{Cd}$ and $\mathrm{Cr}$, and by $40 \mathrm{mg} / \mathrm{l}$ of $\mathrm{Cu}$ and $\mathrm{Ni}$ (Aydinalp and Marinova 2009). Ar at $20-500 \mu \mathrm{M}, \mathrm{Cd}$ at $10-500 \mu \mathrm{M}$ and $\mathrm{Hg}$ at $5-50 \mu \mathrm{M}$ negatively impacted root and shoot biomass of artichoke and savory grown hydroponically (Karimi et al. 2013). HMS negatively impacted wheat growth as 

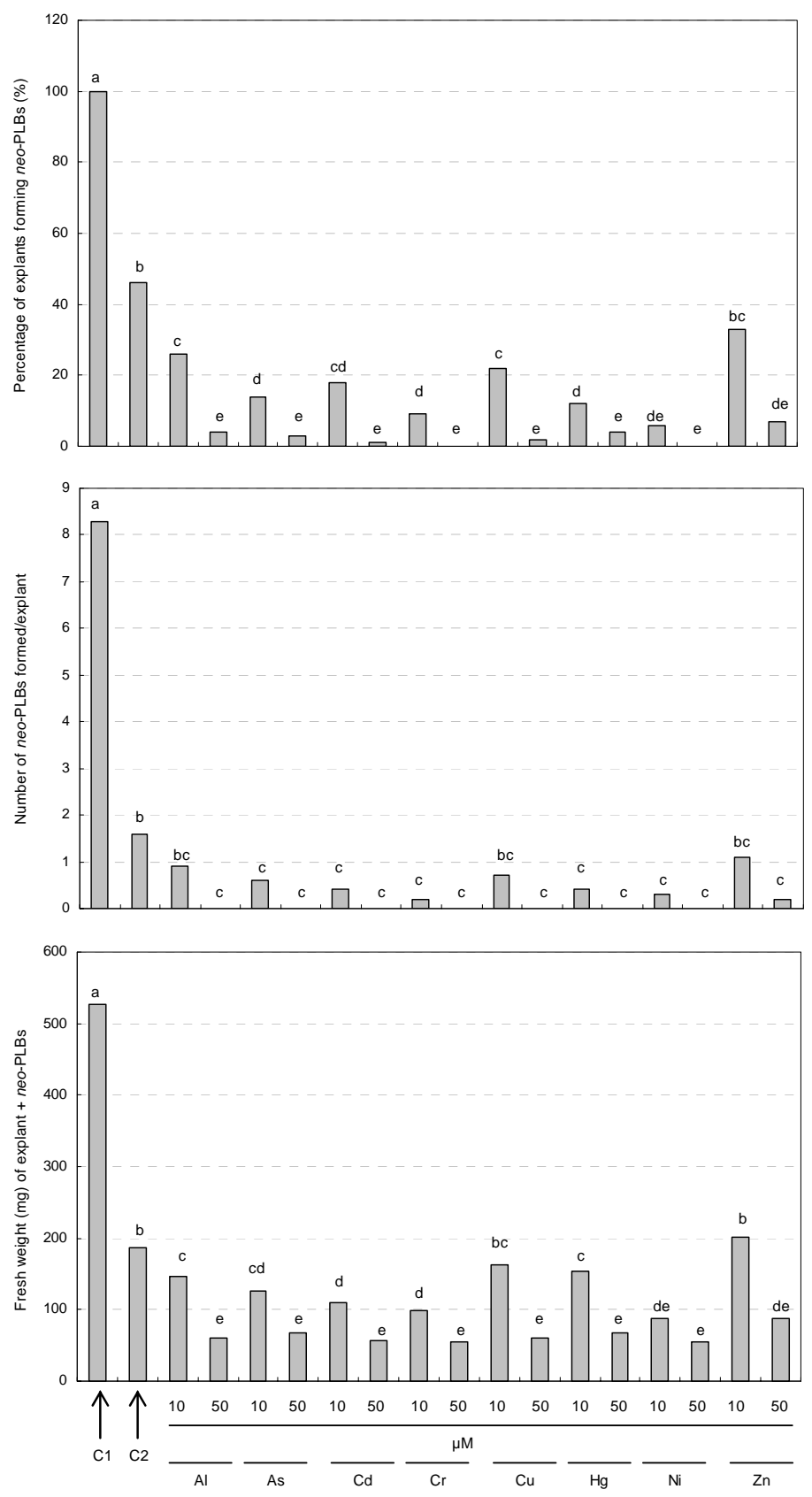

Fig. 1. The response of hybrid Cymbidium Twilight Moon 'Day Light' to different concentrations of 8 heavy metals ( $\mathrm{Al}, \mathrm{As}, \mathrm{Cd}, \mathrm{Cr}, \mathrm{Cu}, \mathrm{Hg}, \mathrm{Ni}, \mathrm{Zn}$ ). Since no neo-PLB formation occurred at or above $100 \mu \mathrm{M}$, graphs only represent 10 and $50 \mu \mathrm{M}$. Mean values with by the same letter are not significantly different based on DMRT $(\mathrm{p}=0.05) . \mathrm{n}=90(10 \times 3 \times 3) . \mathrm{C}=\mathrm{Control} ; \mathrm{C} 1=\mathrm{TC}+\mathrm{PGRs}$ $(0.1 \mathrm{mg} / \mathrm{l} \mathrm{NAA}+0.1 \mathrm{mg} / \mathrm{l} \mathrm{Kn}) ; \mathrm{C} 2$ = TC - PGRs; PGR, plant growth regulator; PLB = Protocormlike body; TC = Teixeira Cymbidium medium No. 1 (Teixeira da Silva 2012). 
follows: $\mathrm{Cd}>\mathrm{Cu}>\mathrm{Ni}>\mathrm{Zn}>\mathrm{Pb}>\mathrm{Cr}$ (Athar and Masood 2002) while poplar in vitro cultures were most affected by $\mathrm{Cu}$, followed by $\mathrm{Pb}$, then $\mathrm{Al}$ (Bojarczuk 2004). Nopalea cochenillifera was tolerant up to $100 \mu \mathrm{M} \mathrm{K} \mathrm{K}_{2} \mathrm{Cr}_{2} \mathrm{O}^{7}$, and was thus considered to be a Cr-hyper-accumulator (Adki et al. 2013). $\mathrm{Cr}$ is a widespread industrial pollutant (Shanker et al. 2005). Low levels of Cd $(100-200 \mu \mathrm{M})$ increased the biomass of potato in vitro Gonçalves et al. (2009). $100 \mu \mathrm{M} \mathrm{CuSO}_{4}$ and $300 \mu \mathrm{M}$ of $\mathrm{ZnSO}_{4}$ improved Withania somnifera shoot formation (Fatima et al. 2011). In vitro screening is an effective way of screening for HM-tolerant clones (Di Lonardo et al. 2011). The physiological basis behind HM detoxification by plants is explained in detail by Hossain et al. (2012), and specifically for Cd by Gill et al. (2011).

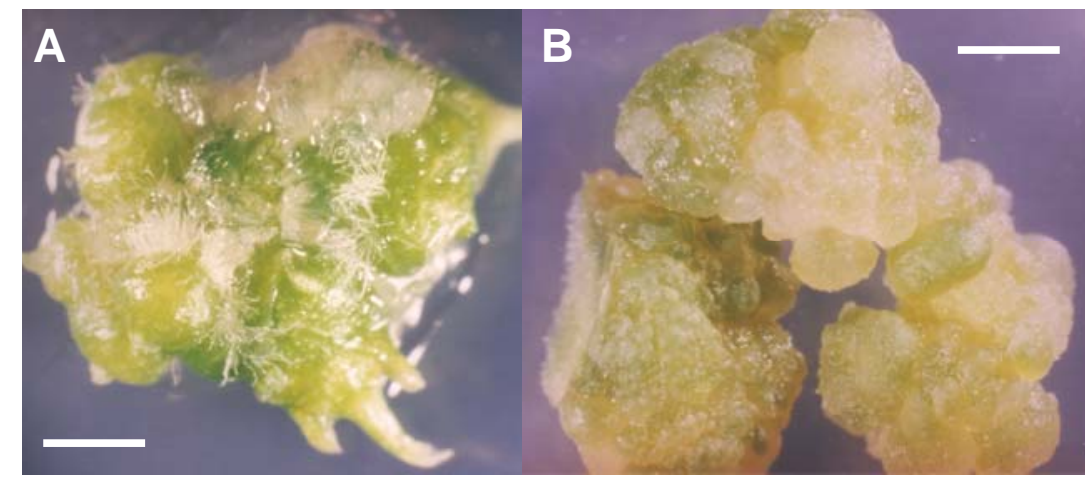

Fig. 2. Growth and development of hybrid Cymbidium Twilight Moon 'Day Light' neoPLBs in solid basal TC (Teixeira da Silva 2012) medium under control conditions (no HMs) (A). Typical response under 10 and $50 \mu \mathrm{M}$ of any $\mathrm{HM}$, even in the presence of 100 and $400 \mathrm{mg} / \mathrm{l}$ of nano-SiO 2 and nano- $-\mathrm{TiO}_{2}$ (B). Bar $=1 \mathrm{~mm}$.

Not all reports on the use of nanoparticles are positive. For example, Yang and Watts (2005) reported that $2000 \mathrm{mg} / \mathrm{l}$ of nano- $\mathrm{Al}_{2} \mathrm{O}_{3}$ significantly inhibited root elongation in maize, cucumber, soybean, cabbage and carrot. Lin and Xing (2007) showed that nano- $\mathrm{Al}_{2} \mathrm{O}_{3}$ particles was phytotoxic to maize root elongation, while Salama (2012) showed that 80 and $100 \mathrm{mg} / \mathrm{l}$ of $\mathrm{Ag}$ nanoparticles significantly inhibited shoot and root elongation of common bean (Phaseolus vulgaris L.) and corn (Zea mays L.). $\mathrm{TiO}_{2} \mathrm{NPs}$ improved wheat (Triticum aestivum L.) root and shoot fresh weights in the presence of 10 and $100 \mathrm{mg} / \mathrm{l}$ but higher concentrations (1000-2000 mg/l) decreased them (Mahmoodzadeh et al. 2013). Pd-nanoparticles were toxic to kiwi-fruit pollen (Speranza et al. 2010).

A search of the literature did not reveal any study on the use of HMs for in vitro orchid regeneration or toxicity assays. 
The logic, however, is that orchids would most likely never be exposed to HMs under normal in vitro or greenhouse growth conditions. Nonetheless, it would be important to examine this potential to phytoremediate or tolerate HMs, even if only as a fundamental study. At an extreme stretch of the imagination, and as an example, one could envision the use of HM-tolerant orchids, developed through in vitro screening, for the use of phytoremediation using ornamental plants. Key questions that need still to be answered are: (a) What is the biochemical reason for the toxicity observed? (b) What is the mechanism by which an orchid plant takes up and responds to a HM, and is it similar to other higher plants? (c) To what level and in what organelles and parts of the plant are HMs accumulated, or used?

\section{Acknowledgement}

The author thanks Prof. Michio Tanaka for research support and use of facilities. The author declares no conflicts of interest, financial, or otherwise.

\section{References}

Adki VS, Jadhav JP and Bapat VA (2013) Nopalea cochenillifera, a potential chromium (VI) hyperaccumulator plant. Environ. Sci. Pollut. Res. Int. 20(2): 1173-1180.

Athar R and Masood A (2002) Heavy metal toxicity; Effect on plant growth and metal uptake by wheat and on free living Azotobacter. Water Air Soil Pollut. 138: 165-180.

Aydinalp C and Marinova S (2009) The effects of heavy metals on seed germination and plant growth on alfalfa plant (Medicago sativa). Bulgarian J. Agric. Sci. 15(4): 347-350.

Bojarczuk K (2004) Effect of toxic metals on the development of poplar (Populus tremula L. $\times$ P. alba L.) cultured in vitro. Polish J. Environ. Stud. 13(2): 115-120

Castiglione MR and Cremonini R (2009) Nanoparticles and higher plants. Caryologia 62: 161-165.

Di Lonardo S, Capuana M, Arnetoli M, Gabbrielli R and Gonnelli C (2011) Exploring the metal phytoremediation potential of three Populus alba $\mathrm{L}$. clones using an in vitro screening. Environ. Sci. Pollut. Res. Int. 18(1): 82-90.

Doran P (2009) Application of plant tissue cultures in phytoremediation research: incentives and limitations. Biotechnol. Bioeng. 103: 60-76.

Fatima N, Ahmad N and Anis M (2011) Enhanced in vitro regeneration and change in photosynthetic pigments, biomass and proline content in Withania somnifera L. (Dunal) induced by copper and zinc ions. Plant Physiol. Biochem. 49(12): 1465-1471.

Gill SS, Khan NN, Anjum NK and Tuteja N (2011) Amelioration of cadmium stress in crop plants by nutrients management: morphological, physiological and biochemical aspects. Plant Stress 5(1): 1-23. 
Gonçalves JF, Antes FG, Maldaner J, Pereira LB, Tabaldi LA, Rauber R, Rossato LV, Bisognin DA, Dressler VL, Flores EM and Nicoloso FT (2009) Cadmium and mineral nutrient accumulation in potato plantlets grown under cadmium stress in two different experimental culture conditions. Plant Physiol. Biochem. 47(9): 814-821.

Haghighi M, Daneshmand B, Heidarian S and Teixeira da Silva JA (2012) The effect of $\mathrm{Ti}$ amendment in $\mathrm{N}$-withholding nutrient solution on nutrient uptake of tomato. Biol. Trace Element Res. 150(1): 381-390.

Haghighi M, Teixeira da Silva JA, Mozafariyan M and Afifipour Z (2013) Can Si and nano-Si alleviate the effect of drought stress induced by PEG in seed germination and seedling growth of tomato? Minerva Biotecnologica 25(1): 17-22.

Hossain MM, Kant R, Van PT, Winarto B, Zeng S-J and Teixeira da Silva JA (2013) The application of biotechnology to orchids. Critical Rev. Plant Sci. 32(2): 69-139

Hossain MA, Piyatida P, Teixeira da Silva JA and Fujita M (2012) Molecular mechanism of heavy metal toxicity and tolerance in plants: central role of GSH in reactive oxygen species and methylglyoxal detoxifications and heavy metal chelation. J. Bot. 2012, ID 872875 .

Karimi N, Khanahmadi M and Soheilikhah Z (2013) The effect of arsenic and heavy metals on growth and metal accumulation by artichoke (Cynara scolymus L.) and savory (Satureja hortensis L.). Iranian J. Plant Physiol. 3(3): 737-747.

Liang Y, Sun W, Zhu Y and Christie P (2007) Mechanisms of silicon-mediated alleviation of abiotic stresses in higher plants - A review. Environ. Pollut. 147: 422-428.

Lin D and Xing B (2007) Phytotoxicity of nanoparticles: inhibition of seed germination and root growth. Environ. Pollut. 150: 243-50.

Mahmoodzadeh H, Aghili R and Nabavi M (2013) Physiological effects of $\mathrm{TiO}_{2}$ nanoparticles on wheat (Triticum aestivum). Technical J. Engineering Applied Sciences 3(14): 1365-1370.

Manousaki E and Kalogerakis N (2011) Halophytes - An emerging trend in phytoremediation. Intl. J. Phytoremediation 13(10): 959-969.

Marshner H (1995) Mineral Nutrition of Higher Plants. Academic Press Inc. Ltd, London.

Meharg AA and Hartley-Whitaker J (2002) Arsenic uptake and metabolism in arsenic resistant and nonresistant plant species. New Phytol. 154: 29-43.

Mousavi SR and Rezaei M (2011) Nanotechnology in agriculture and food production. J. Appl. Environ. Biol. Sci. 1(10): 414-419, 2011.

Nehnevajova E, Herzig R, Erismann K-H and Schwitzgúebel JP (2007) In vitro breeding of Brassica juncea L. to enhance metal accumulation and extraction properties. Plant Cell Rep. 26: 429-437.

Pilon-Smits EAH (2005) Phytoremediation. Ann. Rev. Plant Biol. 56(1): 15-39.

Rai MJ, Kalia RK, Singh R, Gangola MP and Dhawan AK (2011) Developing stresstolerant plants through in vitro selection - An overview of the recent progress. Environ. Expt. Bot. 71: 89-98.

Salama HMH (2012) Effects of silver nanoparticles in some crop plants, common bean (Phaseolus vulgaris L.) and corn (Zea mays L.). Int. Res. J. Biotechnol. 3(10): 190-197. 
Shanker AK, Cervantes C, Loza-Tavera H and Avudainayagam S (2005) Chromium toxicity in plants. Environ. Int. 31: 739-753.

Speranza A, Leopold K, Maier M, Taddei AR and Scoccianti V (2010) Pd-nanoparticles cause increased toxicity to kiwifruit pollen compared to soluble $\mathrm{Pd}(\mathrm{II})$. Environ. Pollut. 158(3): 873-882.

Teixeira da Silva JA (2012) New basal media for protocorm-like body and callus induction of hybrid Cymbidium. J. Fruit Ornamental Plant Res. 20(2): 127-133

Teixeira da Silva JA (2013a) Orchids: advances in tissue culture, genetics, phytochemistry and transgenic biotechnology. Floriculture Ornamental Biotech. 7(1):1-52.

Teixeira da Silva JA (2013b) The role of thin cell layers in regeneration and transformation in orchids. Plant Cell, Tiss. Org. Cult. 113(2): 149-161

Teixeira da Silva JA, Chan M-T, Sanjaya Chai M-L and Tanaka M (2006a) Priming abiotic factors for optimal hybrid Cymbidium (Orchidaceae) PLB and callus induction, plantlet formation, and their subsequent cytogenetic stability analysis. Sci. Hortic. 109(4): 368-378.

Teixeira da Silva JA and Dobránszki J (2013) How timing of sampling can affect the outcome of the quantitative assessment of plant organogenesis. Sci. Hortic. 159: 59-66.

Teixeira da Silva JA, Singh N and Tanaka M (2006b) Priming biotic factors for optimal protocorm-like body and callus induction in hybrid Cymbidium (Orchidaceae), and assessment of cytogenetic stability in regenerated plantlets. Plant Cell, Tiss. Org. Cult. 84(2): 119-128.

Teixeira da Silva JA and Tanaka M (2006) Embryogenic callus, PLB and TCL paths to regeneration in hybrid Cymbidium (Orchidaceae). J. Plant Growth Reg. 25(3): 203-210.

Teixeira da Silva JA, Yam T, Fukai S, Nayak N and Tanaka M (2005) Establishment of optimum nutrient media for in vitro propagation of Cymbidium Sw. (Orchidaceae) using protocorm-like body segments. Prop. Ornamental Plants 5(3): 129-136.

Vacin E and Went FW (1949) Some pH changes in nutrient solutions. Bot. Gaz. 110: 605613.

Yang L and Watts DJ (2005) Particle surface characteristics may play an important role in phytotoxicity of alumina nanoparticles. Toxicol. Lett. 158: 122-132. 